\title{
Kraniyal görüntüleme bulguları ile akçaağaç şurubu idrar hastalığı
}

\section{Maple syrup urine disease with cranial imaging findings}

Yusuf Kale $^{1} \quad$ Ece Karaoğlu ${ }^{2}$

${ }^{1}$ Gaziantep Kadın Doğum ve Çocuk Hastalıkları Hastanesi, Yenidoğan Ünitesi, Gaziantep, Türkiye

${ }^{2}$ Gaziantep Dr. Ersin Arslan Devlet Hastanesi, Radyoloji Kliniği, Gaziantep, Türkiye

\section{Öz}

Dallı-zincirli ketoasidüri olarak da bilinen Akçaağaç şurubu idrar hastalığı (MSUD) dallı-zincirli alfa ketoasit dehidrogenaz kompleks aktivitesindeki yetersizliğinden kaynaklanır. Otozomal resesif olarak kalıtılan bir hastalıktır. Yenidoğanda huzursuzluk, emme problemleri, kusma, letarji, distoni ve idrarda akçaağacı kokusu ile karakterizedir. Burada MSUD tanısı alan olgunun kraniyal manyetik rezonans bulguları ile birlikte sunulmasını ve yönetiminin tartışılmasını amaçladık.

Anahtar Sözcükler: Akçaağaç şurubu idrar hastalığı, yenidoğan, yönetim.

\begin{abstract}
Maple syrup urine disease (MSUD) also known as branched-chain ketoaciduria, is caused by a deficiency of branched-chain alpha-ketoacid dehydrogenase complex. It has autosomal recessive inheritance. It is characterized by irritability, feeding problems, vomiting, lethargy, dystonia and a maple syrup odor of the urine in newborn infants. Herein we aimed to report a case of MSUD with its MR imaging findings and to discuss the management for this case.
\end{abstract}

Keywords: Maple syrup urine disease, newborn, management.

\section{Giriş}

Akçaağaç şurubu idrar hastalığı (MSUD), dallı zincirli aminoasitlerin metabolizmasındaki genetik defektten kaynaklanan, otozomal resesif olarak kalıtılan metabolik bir hastalıktır. Alfa-ketoasit dehidrogenaz kompleks aktivitesindeki yetersizlik sonucunda valin, lösin ve izolösin katabolizmasındaki duraksama olması nedeniyle plazma, idrar ve beyin omurilik sıvısında dallı zincirli aminoasitlerin ketoasitleri birikir. Kraniyal MR ile görüntülemede beyin ödemi, miyelinizasyonda gecikme ve difüzyon kısıtıı̆ı̆ı saptanması tipiktir (1-3). Tanı plazma lösin, izolösin, valin, alloizolösin düzeyinde artış ile alanin düzeyindeki azalmanın tespiti ve idrarda lösin, izolösin, valin ve onların ketoasidlerinde artış saptanması ile konulur (4). Yaklaşık olarak 1: 185.000940.000 sıklığında görülür (5). Toksik metabolitlerin birikmesi ile beslenme sorunları, ciddi metabolik asidoz, ensefalopati bulguları ve idrarda çemen ya da yanmış şeker kokusu duyulabilir (6).

\footnotetext{
Yazışma Adresi: Yusuf Kale

Gaziantep Kadın Doğum ve Çocuk Hastalıkları Hastanesi, Yenidoğan Ünitesi, Gaziantep, Türkiye

Makalenin Geliş Tarihi: 31.05.2016 Kabul Tarihi: 01.08.2016
}

\section{Olgu Sunumu}

Eşi ile amca çocukları olan 32 yaşındaki annenin üçüncü gebeliğinden birinci yaşayan olarak normal vajinal yol ile 38 haftalık, 3190 gram ağırlığında doğan erkek bebeğin apgar skoru 1. ve 5. dakikada sırası ile 8 ve 9 idi. Annenin gebeliği sırasında düzensiz takip edildiği, ilk gebeliğinin sekiz aylık iken ölü doğum ile sonlandığı öğrenildi. Hastanın kız kardeşinin 20 günlük iken sebebi bilinmeyen bir hastalıktan dolayı öldüğü öğrenildi. Hasta 5 günlük iken emmeme, solunum sıkıntısı, nöbet geçirme ve aktivitede azalma şikayeti ile yenidoğan yoğun bakım ünitesine yatırıldı. Fizik muayenede, vücut ağırlığı 3190 gram (25-50 p), boy $49 \mathrm{~cm}(25-50$ p), baş çevresi $34 \mathrm{~cm} \mathrm{(25} \mathrm{p)} \mathrm{olarak} \mathrm{ölçüldü.} \mathrm{Vücut} \mathrm{ısısı} 36.5{ }^{\circ} \mathrm{C}$, nabız $146 / \mathrm{dk}$ ve solunum sayısı $66 / \mathrm{dk}$. idi. Genel durumu kötü olan hastada inleme, çekilmeli solunum, letarjik görünüm mevcut idi. Kardiyovasküler sistem muayenesinde $1 / 6$ sistolik üfürüm duyuldu. Kollar fleksiyonda, bacaklar ekstansiyonda, çaprazlanmış görünümde idi. Yenidoğan refleksleri alınamayan hastanın santral hipotonisitesi mevcuttu. İdrarında yanmış şeker (çemen) kokusu dikkat çekmekteydi. Solunumu yüzeyelleşen, siyanozu olan hasta entübe edilerek mekanik ventilatörde izleme alındı. Hastada sepsis dışlanamadığı için antibiyotik tedavisi düzenlendi. 
Laboratuvar incelemelerinde tam kan sayımı, kan şekeri, kan gazı, serum elektrolitleri, C-reaktif protein değeri, böbrek fonksiyon testleri ve karaciğer enzimleri normal sınırlarda idi. Kan kültüründe üreme olmadı. Metabolik tetkikleri gönderildi. Amonyak ve laktat değerleri normal sınırlarda idi. Tüm abdomen ve transfontanel ultrasonda patolojik bulgu saptanmadı. Ekokardiyografide sekundum küçük $A S D$ ve PFO mevcuttu. Çekilen elektroensefelografisinde frontosantralde keskin dalga deşarjları saptandı. Yatışının 2. gününde nazal devamlı pozitif hava yolu basıncı ile takibe geçildi. Total parenteral nütrisyon (TPN) başlandı. Göz dibi muayenesinde anormal bulgu saptanmadı. Postnatal 10. gününde çekilen kraniyal MR'da T1 ağırlıklı görüntüde serebellar pedinkülde myelinizasyona ait sinyal artışı, T2 ağırlıklı görüntüde periventriküler derin beyaz cevherde, internal kapsül posterior bacağında sinyal artışları ve diffüzyon ağırlıklı görüntülerde bilateral internal kapsül posterior bacağında, kortikospinal traktta ve ponsta difüzyon kısıtlanması saptandı (Şekil-1). Metabolik tetkikleri çıkmadan mevcut kraniyal MR bulguları ile MSUD olabileceği düşünüldü. Hızlı program kan aminoasitleri çalışıldı, serum lösin düzeyi $2007 \mu \mathrm{mol} / \mathrm{L}$ (N: 55-149) saptandı. Hastaya MSUD tanısı konularak özel diyet ile beslenme başlandı. Bir hafta sonra bakılan Iösin düzeyi $785 \mu \mathrm{mol} / \mathrm{L}$ idi. Postnatal 20 günlük iken çocuk metabolizma hastalıkları bölümüne gelmek üzere taburcu edildi.

\section{Tartışma}

MSUD, ketoasit dehidrogenaz enzim eksikliğine bağlı olarak dallı-zincirli aminoasitlerin metabolizmasındaki bozukluk sonucu gelişir (1). Metabolik bozukluğun ağırlığı hastalığın şiddetini belirler. Biriken metabolitler nörotoksiktir ve acilen tedavi edilmesi gerekir.

En sık rastlanan klasik neonatal tipinde hastalar doğumda normaldir, bulgular yaşamın ilk haftasında ortaya çıkar.
Hastalığın akut döneminde kusma, letarji, beslenme bozukluğu, huzursuzluk, tiz sesle ağlama, hipotoni, hipertoni, hipoglisemi, metabolik asidoz, konvülziyon, ekstremitelerde distonik ekstansiyon, koma gibi semptomlar görülebilir. Erken tedavi edilmezse ölüme neden olabilen metabolik kriz ortaya çıkar (5) Sunulan olguda 5 günlük iken letarji ve emme güçlüğü ile başvuran, idrarında yanmış şeker kokusu bulunan karakteristik MSUD kliniği olan bir olgu idi. MSUD tanısı uygun tarama prosedürleri ile ilk bir hafta içinde mümkündür. Erken tanı ve tedavi ile nörolojik sekellerde azalma sağlanabilir (6).

MSUD hastalarında serebral iskeminin patogenezinde apoptozis önemlidir ve mikrovasküler dolaşımdaki bozukluk gelişmesi sonucu sitotoksik ödem ortaya çıkar (7). Yenidoğan metabolik hastalıklarında, beyin bozukluklarının tespitinde kraniyal MR'nin spesifitesi sınırlıdır. MSUD hastalarında kraniyal MR bulgusu olarak akut dönemde beyin ödemi, serebellar beyaz cevher, posterior beyin sapı, serebral pedinküller, internal kapsülün posterior bacağı ve posterior centrum semiovalede ödem ve difüzyon kısıtlılığı saptanması spesifiktir $(8,9)$. Bizim hastamızda da serebellar pedinkülde myelinizasyona ait sinyal artışı ve periventriküler derin beyaz cevherde, internal kapsül posterior bacağında sinyal artışları (ödem) izlenmekte idi. Difüzyon MR beyin matürasyonun ölçülmesinde ve beyaz cevher hastalıklarının tanısında önemli bir yere sahiptir $(9,10)$. Bu hastalarda myelinizasyonda gecikme vardır. Hastamızın difüzyon ağırıklı beyin MR'ında bilateral internal kapsül posterior bacağında, kortikospinal traktta ve ponsta difüzyon kısıtlanması vardı.

Sonuç olarak, MSUD nadir görülen, erken tedavi ile nörolojik sekellerin önlenmesi mümkün olan bir hastalıktır. Bu olgu ile ensefalopati bulguları olan ve ayırıcı tanısında metabolik hastalık olabileceği düşünülen hastalarda kraniyal görüntüleme bulgularının tanıda yol gösterici olabileceği vurgulanmak istenmiştir.
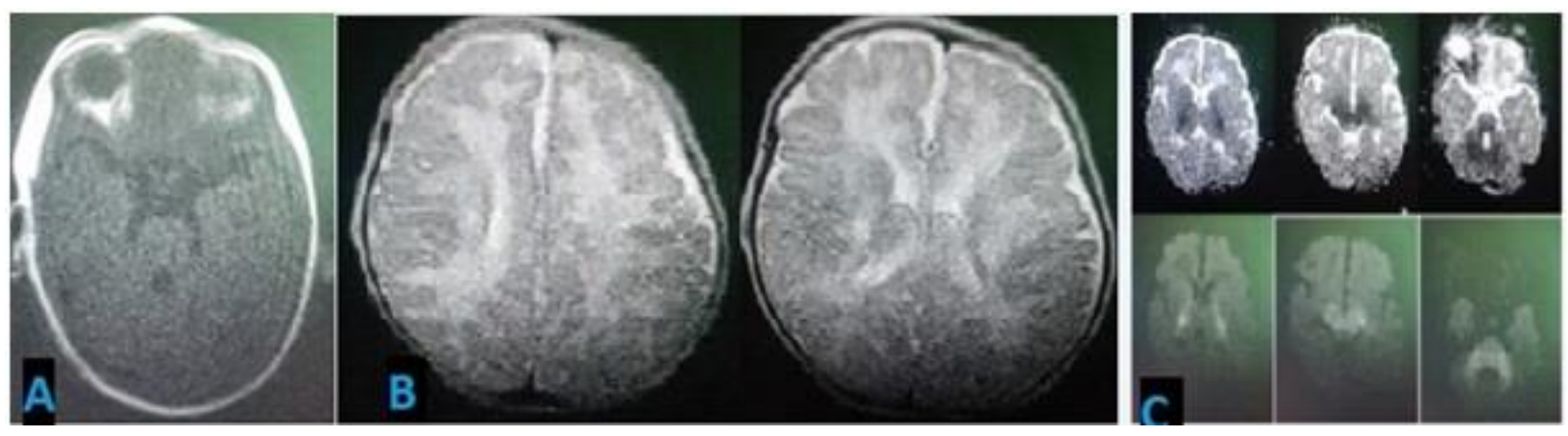

Şekil-1. A. T1 ağırıklı görüntüde serebellar pedinkülde myelinizasyona ait sinyal artışı dikkat çekmektedir. B. T2 ağırlıklı görüntüde periventriküler derin beyaz cevherde, internal kapsül posterior bacağında sinyal artışları izlenmektedir (ödem). C. Diffüzyon ağırıklı görüntülerde bilateral internal kapsül posterior bacağında, kortikospinal traktta ve ponsta difüzyon kısıtlanması görülmektedir. 


\section{Kaynaklar}

1. Kilicarslan R, Alkan A, Demirkol D, Toprak H, Sharifov R. Maple syrup urine disease: Diffusion-weighted MRI findings during acute metabolic encephalopathic crisis. Jpn J Radiol 2012;30(6):522-25.

2. Cavalleri F, Berardi A, Burlina AB, Ferrari F, Mavilla L. Diffusionweighted MRI of maple syrup urine disease encephalopathy. Neuroradiology 2002;44(6):499-502.

3. Jong SH, Taik-Kun K, Baik-Lin E. Maple syrup urine disease encephalopathy: A follow-up study in the acute stage using diffusion-weighted MRI. Pediatr Radiol 2004;34(2):163-6.

4. Morton DH, Strauss KA, Robinson DL, Puffenberger EG, Kelley RI. Diagnosis and treatment of maple syrup disease: A study of 36 patients. Pediatrics 2002;109(6):999-1008.

5. Ogier de Baulny H, Saudubray JM. Branched-chain organic acidurias. Semin Neonatol 2002;7(1):65-74.

6. Simon E, Fingerhut R, Baumkötter J, Konstantopoulou V, Ratschmann R, Wendel U. Maple syrup urine disease: Favourable effect of early diagnosis by newborn screening on the neonatal course of the disease. $J$ Inherit Metab Dis 2006;29(4):532-37.

7. Xia W, Yang W. Diffusion-weighted magnetic resonance imaging in a case of severe classic maple syrup urine disease. $J$ Pediatr Endocrinol Metab 2015;28(7-8):805-8.

8. Cakmakci H, Pekcevik Y, Yis U, Unalp A, Kurul S. Diagnostic value of proton MR spectroscopy and diffusion-weighted MR imaging in childhood inherited neurometabolic brain diseases and review of the literature. Eur J Radiol 2010;74(3):161-71.

9. Mascalchi M, Filippi M, Floris R, Fonda C, Gasparotti R, Villari N. Diffusion-weighted MR of the brain. Methodology and clinical application. Radiol Med 2005;109(3):155-97.

10. Jain A, Jagdeesh $\mathrm{K}$, Mane R, Singla S. Imaging in classic form of maple syrup urine disease: A rare metabolic central nervous system. J Clin Neonatol 2013; 2(2): 98-100. 